\title{
Implementasi Sistem Keuangan Desa (Siskeudes) Studi Kasus pada Desa Besuki Kecamatan Besuki Kabupaten Situbondo
}

\author{
Sulistyowati ${ }^{*}$, Norita Citra $\mathrm{Y}^{2}$, Elok Fitriyah ${ }^{3}$
}

1,2,3 Jurusan Akuntansi Program S1, Universitas Muhammadiyah Jember

\author{
A R T I C L E I N F O \\ Article history: \\ Received 19 May 2019 \\ Received in revised form \\ 16 June 2019 \\ Accepted 15 July 2019 \\ Available online 30 August \\ 2019 \\ Kata Kunci: \\ Implementasi Sistem \\ Keuangan Desa (Siskeudes) \\ Keywords: \\ Implementation of the \\ Village Financial System \\ (Siskeudes)
}

\begin{abstract}
A B S T R A K
Pengelolaan keuangan desa untuk penyelenggaraan pemerintah di Desa Besuki tidak terlepas dari faktor keuangan sebagai sarana terwujudnya pengelolaan keuangan desa yang lebih baik, aplikasi sistem keuangan desa yang telah dikembangkan pemerintah desa untuk tata kelola desa guna mempermudah pengelolaan keuangan desa agar lebih transparan dan akuntabel. Tujuan dari penelitian untuk mengetahui Implementasi Sistem Keuangan Desa (Siskeudes) Desa Besuki Kecamatan Besuki Kabupaten Situbondo. Peneliti menjelaskan menggunakan metode deskriptif kualitatif. Hasil penelitian menunjukkan bahwa implementasi sistem keuangan desa sudah cukup baik, hanya saja ada ketidaksesuaian dari sisi pertanggungjawaban yakni belum bisa paparkan kepada masyarakat.
\end{abstract}

\section{A B S T R A C T}

The village financial management finance for the administration of the village in Besuki village is inseparable from financial factors, means to achieve better village financial management, the application of the village financial system that developed to facilitate village financial management to be more transparent and accountable. The purpose of the study was to find out the Implementation of the Village Financial System (Siskeudes) in Besuki Village, Besuki District, Situbondo Regency. The researcher explained using qualitative descriptive methods. The results of the study indicate that the implementation of the village financial system has been quite good, except that there is a discrepancy in terms of accountability, which has not been able to explain to the public.

\footnotetext{
* Corresponding author.

E-mail addresses: Sulistowati190597@gmail.com (Sulistyowati)
} 


\section{Pendahuluan}

Pada sistem keuangan pemerintah yang berlaku di Indonesia, menurut Undang-undang No. 6 Tahun 2014 yakni Pasal 1 ayat 1 yang menjelaskan desa merupakan satu kesatuan masyarakat hukum yang mempunyai batas dengan wilayah yang berwenang guna mengatur serta mengurus urusan kepemerintahan, dan kepentingan masyarakat setempat yang berdasarkan prakarsa masyarakat, serta hak dan asal usul yang diakui dan dihormati dalam suatu sistem pemerintahan Negara Kesatuan Republik Indosesia. Dalam Pelaksanaan keuangan desa yang sesuai dengan Peraturan Menteri Dalam Negeri No.113 Tahun 2014 yakni Pengelola Keuangan Desa merupakan semua hak dan kewajiban desa yang dinilai dengan sejumlah uang serta segala sesuatu yang berupa uang dan barang yang berpengaruh dengan pelaksanaan hak dan kewajiban didesa. Sementara itu pengelola keuangan desa adalah seluruh rangkaian pelaksanaan kegiatan yang dilalui dengan tahapan perencanaan, pelaksanaan, penatausahaan, pelaporan dan pertanggungjawaban yang telah dilaksanakan dalam tahun anggaran, yang dihitung mulai 1 Januari hingga dengan 31 Desember.

Undang-undang No. 6 Tahun 201 mengenai desa menegaskan pada tahun 2015 mendapat serta memperoleh anggaran dana sejumlah 10\% dari APBN. Anggaran dana ini akan diberikan langsung yakni kepada kepala desa tanpa melalui perantara yang sebelumnya. Dengan diperolehnya alokasi APBN yakni sejumlah $10 \%$ yang akan diterima langsung oleh desa serta mampu mempengaruhi penerimaan desa agar lebih meningkat lagi selain itu, dengan adanya hal ini akan diperlukannya akuntansi dan manajemen sebagai pelaporan keuangan yang baik disetiap desa-desa diIndonesia. Keuangan desa diperoleh dari pendapatan asli desa harus dikelola dengan baik dan jujur demi tercapainya kesejahteraan masyarakat dan pembangunan desa. Peningkatan sumber perekonomian masyarakat dapat melalui kebijakan dana desa.

Laporan keuangan disusun untuk penyedia suatu informasi yang lebih efektif serta relevan sebagai media dari transaki keuangan serta semua kegiatan yang berhubungan dengan aktivitas ekonomi yang dilaksanakan oleh suatu organisasi pelaporan keuangan. Dengan berjalannya suatu perubahan diinstansi keuangan diIndonesia, butuh dilakukannya suatu perubahan didalam berbagai instansi keuangan supaya berjalan lebih baik dan efektif. Perubahan utama yakni perubahan didalam bidang akuntansi pemerintahan yang melalui tahap akuntansi, maka akan menghasilkan sumber informasi keuangan yang tersedia diberbagai pihak serta dilakukan sesuai yang menjadi tujuan dari masing-masing.. Pengelola keungan desa harusnya dilaksanakan sebaik mungkin agar tidak ada lagi kasus penyelewengan didalam pengelola anggaran dana desa.

Pemerintah desa guna membentuk kebijakan didalam pengelolaan keuangan desa, Badan Pengawas Keuangan dan Pembangunan (BPKP) meluncurkan salah satu aplikasi yang bermanfaat guna meningkatkan mutu dari kualitas tata kelola keuangan desa. Untuk melanjutkan upaya pemerintah dalam meningkatkan kesejahteraan masyarakat pedesaan memaluli dana desa, Badan Pengawasan Keuangan dan Pembangunan (BPKP) mengeluarkan aplikasi sistem keuangan desa (Siskeudes) pada Juli tahun 2015 lalu. Aplikasi Sistem Keuangan Desa (Siskeudes) adalah aplikasi yang diluncurkan oleh Badan Pengawasan Keuangan dan Pembangunan (BPKP) dalam meningkatkan kualitas tata kelola keuangan desa agar lebih baik kedepannya. Didalam Siskeudes terdapat program yang ada didalam aplikasi pengelola keuangan desa yang dibuat semudah mungkin menggunakan User Friendly untuk mempermudah penggunaannya dalam pengoperasian aplikasi sistem keuangan desa ini (Siskeudes).

Kabupaten Situbondo khususnya Kecamatan Besuki yang terdapat 15 Desa, namun hanya saja beberapa yang telah menggunakan Aplikasi Sistem Keuangan Desa termasuk Desa Besuki. Kantor Desa Besuki telah menerapkan Aplikasi Sistem Keuangan Desa ini sejak tahun 2017. Pada Kecamatan Besuki terdapat beberapa kendala dalam mengimplementasikan SISKEUDES ini seperti sumber daya manusia yang belum memadai karena juga tiap aparatur desa tidak semuanya paham akuntansi desa juga belum mempunyai prosedur serta dukungan dari sarana dan prasarana dalam tata kelola keuangan, juga belum kritisnya masyarakat mengenai pengelola anggaran pendapatan desa dan belanja desa sehingga menjadi peluang untuk aparatur desa berbuat kecurangan.

Berdasarkan penelitian pendahuluan, Sekretaris Desa Besuki Mukhlis Jayadi, mengatakan bahwa telah melakukan pelatihan yakni dalam mengoperasikan Aplikasi Sistem Keuangan Desa (Siskeudes). Aplikasi Siskeudes diDesa Besuki dioperasikan oleh staf operator desa besuki, dalam segi pelaporan keuangan desa kembali kepada sekertaris desa besuki. Dengan adanya masalah yang terjadi dilapangan dalam proses pengimplementasian Siskeudes ini memang tidak ada kendala yang berarti terdapat kelebihan dan kekurangan dalam aplikasi ini, sehingga disinalah peran dari seorang bendaraha untuk mengatasi agar pengimplementasian Siskeudes ini dapat digunakan secara lancar dan desa dapat menghasilkan laporan keuangan yang lebih akuntabel. 


\section{Metode}

Jenis Penelitian

Pendekatan penelitian ini yakni menggunakan pendekatan deskriptif kualitatif pada Desa Besuki Kecamatan Besuki Kabupaten Situbondo. Ahli Bogdan Taylor (Maleong, 2012) menjelaskan bahwa metode kualitatif yaitu tahapan penelitian yang dapat menghasilkan jenis data deskriptif yakni mencakup penjelasan kalimat tertulis maupun lisan dari individu serta dari perbuatan yang dapat diamati.

Lokasi Penelitian

Lokasi tempat penelitian berada diDesa Besuki Kecmatan Besuki Kabupaten Situbondo. Penelitian dilaksanakan pada bulan Desember 2018.

Informan

1. Husamah Bahres : Kepala Desa Besuki

2. Mukhlis Jayadi S.Pd : Sekretaris Desa Besuki

3. Ria Ayu F. : Bendahara Desa Besuki

4. Diat Priatmana : Staf Operator Siskeudes Desa Besuki

Jenis Data

Penelitian menggunakan dua jenis data yang meliputi : 1 . Data Primer : yakni berupa data yang diperoleh langsung dari lokasi penelitian dengan melalui wawancara dan observasi langsung di Kantor Desa Besuki, dan 2. Data Sekunder : yakni berupa studi pustaka dengan mengumpulakan dokumen serta artikel yang terkait.

Teknik Analisis Data

1. Perencanaan : Perencanaan program Desa Besuki melibatkan bidang pembangunan, pemerintahan, dan kemasyarakatan yang dilakukan oleh Sekretris Desa Besuki.

2. Pelaksanaan : Pelaksanaan dilakukan yakni Bendahara Desa Besuki.

3. Penatausahaan : Penatausahaan dilaksanakan oleh Bendahara Desa Besuki.

4. Pelaporan : Pelaporan disampaikan oleh Kepala Desa Besuki

5. Pertanggungjawaban: Pertanggungjawaban yang dilakukan oleh Kepala Desa Besuki

6. Pengawasan : Badan Perwakilan Desa (BPD) yang melaksanakan tugas pengawasan terhadap pelaksanaan program yang diatasi oleh Pemerintahan Desa Besuki.

\section{Hasil dan pembahasan}

\section{Pengelolaan Sistem Keuangan Desa Besuki}

Tabel 1. Tahap Perencanaan Desa Besuki

\begin{tabular}{|c|c|c|c|}
\hline No & Permendagri Nomor 113 Tahun 2014 & Hasil Data & Keterangan \\
\hline 1 & $\begin{array}{l}\text { Kepala Desa dibantu Sekretaris desa } \\
\text { membuat Peraturan Desa mengenai } \\
\text { APBDes yang berdasarkan RKPDes. }\end{array}$ & $\begin{array}{l}\text { Proses penyusunan peraturan desa } \\
\text { didesa Besuki dilakukan oleh } \\
\text { Sekretaris Desa Besuki. }\end{array}$ & Sesuia \\
\hline 2 & 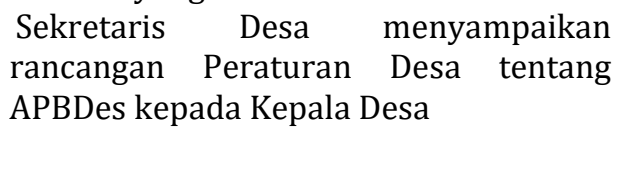 & 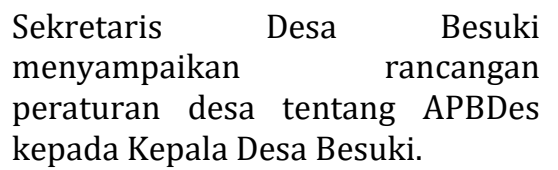 & Sesuai \\
\hline 3 & $\begin{array}{l}\text { Rancangan Peraturan Desa mengenai } \\
\text { APBDes disampaikan oleh Kepala Desa } \\
\text { kepada Badan Permusyawaratan Desa } \\
\text { untuk dibahas dan disepakati bersama. }\end{array}$ & $\begin{array}{lr}\text { Kepala Desa Besuki menyampaikan } \\
\text { rancangan Peraturan } & \text { Desa } \\
\text { mengenai APBDes kepada } & \text { Badan } \\
\text { Permusyawaratan Desa } & \text { untuk } \\
\text { mendapat persetujuan. } & \end{array}$ & Sesuia \\
\hline 4 & $\begin{array}{l}\text { Rancangan Peraturan Desa mengenai } \\
\text { APBDes disepakati bersama paling } \\
\text { lambat bulan Oktober tahun berjalan. }\end{array}$ & $\begin{array}{l}\text { Rancangan Peraturan } \\
\text { mengenai APBDes diDesa Besuki } \\
\text { disepakati bersama bulan } 15 \\
\text { Oktober. }\end{array}$ & Sesuai \\
\hline 5 & $\begin{array}{l}\text { Rancangan Peraturan Desa mengenai } \\
\text { APBDesa yang telah disepakati bersama }\end{array}$ & $\begin{array}{l}\text { Rancangan } \begin{array}{c}\text { Peraturan } \\
\text { mengenai }\end{array} \text { APBDesa yang } \\
\text { sudah }\end{array}$ & Sesuia \\
\hline
\end{tabular}




\begin{tabular}{lll}
\hline disampaikan oleh Kepala Desa kepada & disepakati bersama yang \\
Bupati/Walikota melalui camat paling & disampaikan oleh Kepala Desa \\
lambat 3 (tiga) hari sejak disepakati & Besuki kepada Bupati untuk \\
untuk dievaluasi & & \\
\hline
\end{tabular}

Sumber : Hasil Data Olahan

Dari Tabel 1 Menunjukkan bahwa Pemerintah Desa Besuki telah melakukan tugas-tugasnya dengan baik yakni dalam penyusunan rancangan peraturan desa didesa besuki mengenai APBDes yang disepakati bersama pada tanggal 15 Oktober. Berdasarkan Permendagri 113 Tahun 2014 Pasal 20 Ayat 4 yang mengatur bahwa rancangan Peraturan Desa tentang APBDesa disepakati bersama paling lambat bulan Oktober tahun berjalan.

Tabel 2. Tahap Pelaksanaan Desa Besuki

\begin{tabular}{|c|c|c|c|}
\hline No. & Permendagri Nomor 113 tahun 2014 & Hasil Data & Keterangan \\
\hline 1. & $\begin{array}{l}\text { Semua penerimaan dan pengeluaran } \\
\text { desa dalam pelaksanaan kewenangan } \\
\text { desa dilaksanakan melalui rekening kas } \\
\text { desa. }\end{array}$ & $\begin{array}{l}\text { Didesa Besuki dalam penerimaan dan } \\
\text { pengeluaran desa telah menggunakan } \\
\text { rekening kas untuk kegiatan. }\end{array}$ & Sesuai \\
\hline 2. & $\begin{array}{l}\text { Semua penerimaan dan pengeluaran } \\
\text { desa harus didukung oleh bukti yang } \\
\text { lengkap dan sah. }\end{array}$ & $\begin{array}{l}\text { Pemerintah Desa Besuki diharuskan } \\
\text { untuk setiap pengeluaran dan } \\
\text { penerimaan disertai bukti seperti } \\
\text { kwintansi dll. }\end{array}$ & Sesuai \\
\hline 3. & $\begin{array}{l}\text { Pemerintah desa dilarang melakukan } \\
\text { pungutan sebagai penerimaan desa } \\
\text { selain yang ditetapkan dalam peraturan } \\
\text { desa. }\end{array}$ & $\begin{array}{l}\text { Pemerintah Desa Besuki dilarang untuk } \\
\text { melakukan pungutan karena dianggap } \\
\text { sebagai pemungutan liar. }\end{array}$ & Sesuai \\
\hline 4. & $\begin{array}{l}\text { Bendahara Desa dapat menyimpan } \\
\text { uang dalam Kas Desa pada jumlah } \\
\text { tertentu dalam rangka memenuhi } \\
\text { kebutuhan operasional pemerintah } \\
\text { desa. }\end{array}$ & $\begin{array}{l}\text { Bendahara Desa Besuki menyimpan } \\
\text { uang dalam jumlah dibawah } 5 \text { juta } \\
\text { sebagai memenuhi kebutuhan dari } \\
\text { operasional pemerintahan desa. }\end{array}$ & Sesuai \\
\hline 5. & $\begin{array}{l}\text { Pengeluaran desa mengakibatkan } \\
\text { beban APBDesa yang tidak dapat } \\
\text { dilaksanakan sebelum rancangan } \\
\text { peraturan desa mengenai APBDesa } \\
\text { disahkan menjadi peraturan desa. }\end{array}$ & $\begin{array}{l}\text { Didesa Besuki tidak pernah melakukan } \\
\text { pengeluaran sebelum ditetapkannya } \\
\text { peraturan desa. }\end{array}$ & Sesuia \\
\hline
\end{tabular}

Sumber : Hasil Data Olahan

Dari Tabel 2 Menjelaskan bahwa telah sesuai dengan peraturan, yakni Permendagri 113 Tahun 2014 yakni Pasal 25 Ayat 2 mengenai Bendahara Desa dapat menyimpan sejumlah uang dalam kas desa pada jumlah yang tertentu dalam rangka untuk memenuhi kebutuhan operasional pemerintahan didesa. Pada Desa Besuki menyimpan sejumlah uang dibawah 5 juta untuk memenuhi kebutuhan operasional, untuk kelancaran operasional Bendahara Desa Besuki.

Tabel 3. Tahap Penatausahaan Desa Besuki

\begin{tabular}{|c|c|c|c|}
\hline No & Permendagri Nomor 113 Tahun 2014 & Hasil Data & Keterangan \\
\hline 1. & $\begin{array}{l}\text { Proses penatausahaan dilaksanakan } \\
\text { Bendahara Desa. }\end{array}$ & $\begin{array}{l}\text { Semua proses program penatausahaan } \\
\text { diDesa Besuki dilakukan oleh } \\
\text { Bendahara Desa yaitu Ibu Ria Ayu D.F }\end{array}$ & Sesuai \\
\hline 2. & $\begin{array}{l}\text { Bendahara desa wajib melakukan } \\
\text { pencatatan setiap penerimaan dan } \\
\text { pengeluaran serta melakukan tutup buku } \\
\text { setiap akhir bulan secara tertib. }\end{array}$ & $\begin{array}{l}\text { Bendahara desa melakukan pencatatan } \\
\text { disetiap penerimaan dan pengeluaran } \\
\text { serta melakukan tutup buku dengan } \\
\text { menggunakan Sistem Keuangan Desa } \\
\text { (Siskeudes) }\end{array}$ & Sesuai \\
\hline 3. & $\begin{array}{lrr}\text { Bendahara } & \text { Desa } & \text { diwajibkan } \\
\text { bertanggungjawab atas } & \text { sejumlah uang } \\
\text { yakni } & \text { melalui } & \text { pelaporan }\end{array}$ & $\begin{array}{l}\text { Bendahara Desa Besuki telah } \\
\text { mempertanggungjawabkan sejumlah } \\
\text { uang yang masuk dan keluar sesuai }\end{array}$ & Sesuai \\
\hline
\end{tabular}




\begin{tabular}{ll}
\hline pertanggungjawaban didalam format kas & dengan laporan pertanggungjawaban \\
umum, serta buku pembantu perpajakan, & \\
buku bank. &
\end{tabular}

Dari Tabel 3 menjelaskan bahwa pemerintahan Desa Besuki telah melaksanakan kegiatan-kegiatan yang sesuai dengan aturan Permendagri No. 113 Tahun 2014 Pasal 35 tentang Penatausahaan Keuangan Desa. Bendaraha Desa Besuki telah memahami akan tugas-tugas yang harus dilaksanakan oleh bendahara desa besuki terkait dengan penatausahaan desa.

Tabel 4. Tahap Pelaporan Desa Besuki

\begin{tabular}{|c|c|c|c|}
\hline No. & Permandagri Nomor 113 Tahun 2014 & Hasil Data & Keterangan \\
\hline 1. & $\begin{array}{l}\text { Kepala desa menyampaikan mengenai } \\
\text { laporan realisai pelaksanaan APBDes } \\
\text { kepada Bupati yakni laporan semester } \\
\text { pertama dan semester akhir tahun yang } \\
\text { dianggarkan. }\end{array}$ & 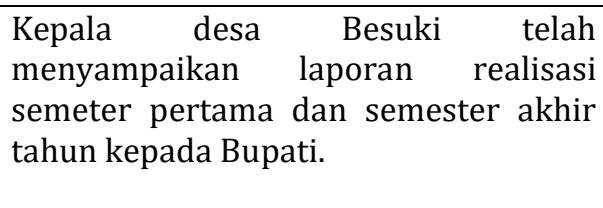 & Sesuai \\
\hline 2. & $\begin{array}{l}\text { Laporan realisasi pelaksanaan APBDes } \\
\text { waktu penyampaian semester pertama } \\
\text { paling lambat pada akhir bulan Juli } \\
\text { tahun berjalan. }\end{array}$ & $\begin{array}{l}\text { Kepala Desa Besuki menyampaikan } \\
\text { laporan realisasi semester pertama } \\
\text { paling lambat tanggal } 30 \text { Juni tahun } \\
\text { berjalan }\end{array}$ & Sesuai \\
\hline 3. & $\begin{array}{l}\text { Laporan semester akhir tahun waktu } \\
\text { penyampaian paling lambat akhir bulan } \\
\text { januari tahun berikutnya. }\end{array}$ & $\begin{array}{l}\text { Penyampaian laporan semester akhir } \\
\text { tahun yang disampaikan Kepala Desa } \\
\text { Besuki pada akhir bulan tanggal } 30 \\
\text { Desember tahun berjalan. }\end{array}$ & Sesuai \\
\hline
\end{tabular}

Sumber : Hasil Data Olahan

Dari Tabel 4 menunjukkan bahwa Pemerintah Desa Besuki dapat melaksanakan tugas dengan tepat waktu terkait pelaporan keuangan desa yakni dengan menyampaikan laporan realisasi pelaksanaan APBDes semester pertama dan semester akhir tahun kepada Bupati dengan cepat dan tepat waktu.

Tabel 5. Tahap Pertanggungjawaban Desa Besuki

\begin{tabular}{|c|c|c|c|}
\hline No & Permendagri Nomor 113 tahun 2014 & Hasil Data & Keterangan \\
\hline 1. & $\begin{array}{l}\text { Kepala Desa menyampaikan pelaporan } \\
\text { atas pertaggungjawaban mengenai } \\
\text { realisasi pelaksanaan APBDesa yang } \\
\text { disampaikan kepada Bupati tiap akhir } \\
\text { tahun. }\end{array}$ & $\begin{array}{l}\text { diDesa Besuki menyampaikan } \\
\text { pelaporan } \\
\text { realisasi pelaksanaan APBDesa yang } \\
\text { disampaikan oleh Kepala Desa Besuki, } \\
\text { beserta Bendahara dan Sekretaris Desa } \\
\text { Besuki. }\end{array}$ & Sesuai \\
\hline 2. & $\begin{array}{l}\text { Pelaporan atas pertanggungjawaban } \\
\text { realisasi pelaksanaan APBDesa } \\
\text { mencakup sumber pendapatan, serta } \\
\text { belanja, dan pembiayaan. }\end{array}$ & $\begin{array}{l}\text { pelaporan pertanggungjawaban } \\
\text { mengenai realisasi pelaksanaan } \\
\text { APBDesa didesa Besuki telah } \\
\text { disampaikan kepada Bupati yang terdiri } \\
\text { dari pendapatan, belanja dan } \\
\text { pembiayaan. }\end{array}$ & Sesuai \\
\hline 3. & $\begin{array}{l}\text { Laporan pertanggungjawaban realisasi } \\
\text { pelaksanaan APBDesa ditetapkan } \\
\text { dengan Peraturan Desa }\end{array}$ & $\begin{array}{llr}\text { Didesa Besuki } & \text { pelaporan } \\
\text { pertanggungjawaban yakni } & \text { realisasi } \\
\text { pelakssanaan APBDesa telah } & \text { disahkan } \\
\text { sesuai peraturan Desa Besuki. }\end{array}$ & Sesuai \\
\hline 4. & $\begin{array}{l}\text { Peraturan Desa mengenai pelaporan } \\
\text { pertanggungjawaban tentang realisasi } \\
\text { pelaksana APBDesa didukung: } \\
\text { - Bentuk format tentang laporan } \\
\text { pertanggungjawaban }\end{array}$ & 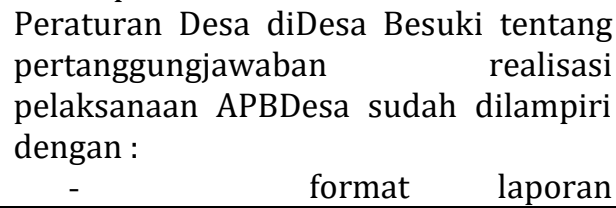 & Sesuai \\
\hline
\end{tabular}




\begin{tabular}{|c|c|c|c|}
\hline & $\begin{array}{l}\text { pelaksanaan APBDesa tahun } \\
\text { anggaran berkenaan. } \\
\text { - Bentuk format tentang laporan } \\
\text { hasil kekayaan Milik desa per } 31 \\
\text { Desember. }\end{array}$ & $\begin{array}{l}\text { realisasi pelaksanaan APBDesa } \\
\text { tahun anggaran berkenaan. } \\
\text { - Laporan kekayaan } \\
\text { milik desa per } 31 \text { Desember tahun } \\
\text { berkenaan. }\end{array}$ & \\
\hline 5. & $\begin{array}{l}\text { Laporan realisasi dan laporan } \\
\text { pertanggungjawaban } \\
\text { pelaksanaan APBDesa diinformasikan } \\
\text { kepada masyarakat secara tertulis dan } \\
\text { dengan media informasi yang mudah } \\
\text { diakses oleh masyarakat. }\end{array}$ & $\begin{array}{l}\text { Belum ada informasi dari Pemerintah } \\
\text { Desa Besuki untuk menginformasikan } \\
\text { mengenai pelaporan realisasi dan } \\
\text { pelaporan pertanggungjawaban kepada } \\
\text { msyarakat Desa Besuki. }\end{array}$ & $\begin{array}{l}\text { Tidak } \\
\text { Sesuai }\end{array}$ \\
\hline 6. & $\begin{array}{l}\text { Media informasi komunikasi mencakup } \\
\text { papan pengumuman, radio komunitas, } \\
\text { dan media informasi lainnya. }\end{array}$ & $\begin{array}{l}\text { diDesa Besuki belum tersedia papan } \\
\text { pengumuman, bahkan radio komunitas } \\
\text { sebagai media informasi untuk } \\
\text { masyarakat. }\end{array}$ & $\begin{array}{l}\text { Tidak } \\
\text { Sesuai }\end{array}$ \\
\hline
\end{tabular}

Sumber : Hasil Data Olahan

Dari Tabel 5 menjelaskan bahwa dalam tahap pertanggungjawaban ada ketidaksesuaian dengan peraturan yang ada karena laporan pertanggungjawaban tidak transparan kepada masyarakat. Juga disebabkan oleh faktor ilmu pengetahuan yang kurang pahamnya masyarakat akan peraturan-peraturan yang ada. Berdasarkan Permandagri No. 113 Tahun 2014 Pasal 40 bahwa laporan realisasi dan laporan pertanggungjawaban realisasi pelaksanaan APBDesa harus disampaikan atau diinformasikan kepada masyarakat melalui papan tulis pengumuman atau media informasi lainnya

\section{Simpulan dan saran}

Berdasarkan hasil analisis diatas, tentang Implementasi Sistem Keuangan Desa (siskeudes) Didesa Besuki Kecamatan Besuki Kabupaten Situbondo, dapat disimpulkan bahwa implementasi sistem keuangan desa (Siskeudes) didesa besuki sudah cukup baik dalam pengelola keuangan desa mencakup, kegiatan perencanaan yang dilaksanakan oleh sekretaris desa, kegiatan pelaksanaan yang dilakukan oleh bendahara desa, kegiatan penatausahaan yang dilakukan oleh bendaraha desa, kegiatan pelaporan serta kegiatan pertanggungjawaban yang dilaksanakan oleh Kepala Desa Besuki telah melakukan tugas dengan cukup baik. Hanya saja kegiatan pertanggungjawaban terjadi ketidaksesuaian atau ketidakterbukaan dalam menyampaikan laporan realisasi APBDes kepada masyarakat Desa Besuki.

Untuk pengelolaan keuangan desa di Desa Besuki kepala desa, bendahara desa dan sekretaris desa seharusnya dapat menyediakan sarana informasi untuk semua masyarakat agar dapat mempermudah masyarakat untuk mendapatkan informasi mengenai pengelolaan keuangan desa sebagai bentuk pertanggungjawaban kepada masyarakat desa besuki kecamatan besuki kabupaten situbondo.

\section{Daftar Rujukan}

Erwan, Agus P. 2015. Implementasi Kebijakan Publik. Yogyakarta : Gava Media

Moleong, Lexy J. 2011. Metode Penelitian Kualitatif (Revisi). Bandung : Remaja Rosdakarya.

Wahab dan Solichin A. 2016. Mengenai Analysis Kebijakan dari Formulasi ke Penyusunan Model Suatu Implementasi Kebijakan. Bumi Aksara: Jakarta http://www.keuangandesa.com/2015/04/pengelolaan-keuangan-desa-dalam-kerangka-tatapemerintahan-yang-baik/

Ghony, Moh. Junaidi, Almanshur, dan Fauzan, 2016. Tentang Metode Penelitian Kualitatif. Yogyakarta.

R. Indra Sarjono S, Sutaryo. 2016. Faktor-faltor Penentu Implementasi E-Government Pemerintah Daerah Di Indonesia.Universitas Sebelas Maret.

Mulyadi dan Deddi. 2015. Tentang Study Kebijakan Publik serta Pelayanan Publik : Konsep dan Aplikasi mengenai Proses Kebijakan Publik dan Pelayanan Publik. Bandung, Jawa Barat. 
Jeacklin Valenia M, Harijanto S, Hendrik Gamaliel. Jurnal Analisis Pengelolaan Keuangan Desa Berdasarkan Pemendagri No. 113 Tahun 2014.

Rahmawati. 2015. Tentang Jurnal Ilmiah Analisis Kesiapan Desa Dalam Pengimplementasian Penerapan UU Nomor 06 Tahun 2014 Mengenai Desa.

I Gusti Ayu Trisna S, Made Arie W, dan Putu Sukma K. 2017. Jurnal Ilmiah Peran Sistem Keuangan Desa (Siskeudes) Terhadap Kinerja Pemerintahan Desa (Study Kasus diDesa Kaba-kaba, Kec. Kediri, Kab. Tabanan.

Ayu Lestari, Sitti Nurhayati N, Jaka Darmawan. 2016. Jurnal Faktor-faktor Yang Mempengaruhi Kesiapan Penerapan Akuntansi Desa. (Studi Kasus Kabupaten Ogan Hilir).

Made Arie W, Nyoman Trisna H. 2017. Jurnal tentang Analisis Pengelola Keuangan Desa Melalui Implementasi Sistem Keuangan Desa (Siskeudes) Sebagai Konteks Disiplin Diri Pada Desa Tigawasa.

Ni Wayan R, 2016. Tentang Good Governance dalam Pengelolaan Anggaran Dana Desa. Universitas Mahasaraswati Denpasar. 